IRA-International Journal of Education \& Multidisciplinary Studies

ISSN 2455-2526; Vol.06, Issue 03 (2017)

Pg. no. 255-259

Institute of Research Advances

https://research-advances.org/index.php/IJEMS

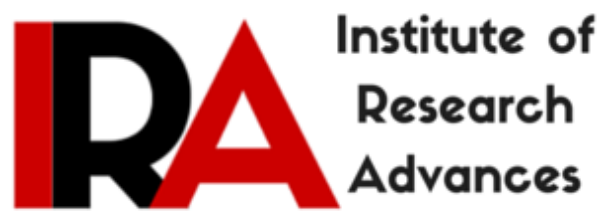

\title{
A Study on Various Factors Affecting the Need for Industry Institute Interaction
}

\section{T. Mary Jones}

Associate Professor \& HOD

PACE Institute of Technology \& Sciences, Ongole, India.

K. Prasanth Kiran

Associate Professor

S. S. N. Engineering College, Ongole, India.

Type of Review: Peer Reviewed.

DOI: http://dx.doi.org/10.21013/jems.v6.n3.p5

\section{How to cite this paper:}

Jones, T., \& Kiran, K. (2017). A Study on Various Factors Affecting the Need for Industry Institute Interaction. IRA International Journal of Education and Multidisciplinary Studies (ISSN 2455-2526), 6(3), 255-259. doi:http://dx.doi.org/10.21013/jems.v6.n3.p5

(C) Institute of Research Advances

\section{(cc) BY-No}

This work is licensed under a Creative Commons Attribution-Non Commercial 4.0 International License subject to proper citation to the publication source of the work.

Disclaimer: The scholarly papers as reviewed and published by the Institute of Research Advances (IRA) are the views and opinions of their respective authors and are not the views or opinions of the IRA. The IRA disclaims of any harm or loss caused due to the published content to any party. 


\begin{abstract}
"Education is the process of facilitating learning or the process of acquiring knowledge, skills and attitude. Education enlightens the people and empowers them towards many issues. An institute is a place where the student is equipped with all the required skills to face the external world. But in the present days there is a wide gap between the needs of the industry and the employability skills of graduates coming out of various professional colleges. Only $3.84 \%$ of engineering students are possessing employability skills and there is no much difference in the other courses. Thus there is a need for industry institute interaction to bridge the gap. This interaction should help the institutes to develop professionals and the industry should get the required personnel.
\end{abstract}

Key Words: Skill gap, Industry Institute Interaction.

\title{
Introduction:
}

Digitalization is the buzzword in the present days. Every transaction is to be done only in online mode. World is experiencing growth in each and every aspect digitalization has completely changed all the activities of the people on Earth. The way of living, working, relaxing, entertaining and maintaining physical and social health. Every process is associated with technology in the present days and most importantly the business. Business has transformed from a mere process of producing and selling to creating and convincing the people to purchase it with their innovative strategies. The meaning of competition has also changed and relative competitors are increasing. The customers are having ability to access and afford the digital world. Thus the form of doing business in the globalised environment is very complex and the corporate world is looking for innovative, smart and multi skilled personnel.

\section{Objectives of the study:}

- To identify the reasons for the skill gap in India

- To suggest the remedial measures to reduce the skill gap in india.

\section{Research Methodology:}

The study is an exploratory research. The research is based purely on secondary data collected from reports published by various research institutes.

\section{Literature Review:}

The industry in order to get the work done in effective manner started to give training to the employees in the initial days. But that was difficult and expensive for all the companies. In this regard the professional courses have started to emerge to meet the needs of the industry. Many companies established the institutes and colleges to prepare candidates suitable to their corporate culture. Later the educational institutes have also started to offer these courses and encouraged the people to be equipped with the required skills to meet the industry needs and thereby they can have good career opportunities. In the initial days the numbers of educational institutes were less and every candidate who qualifies was getting good jobs. But in the recent past we can observe that the industry requirements have changed completely. And on the other hand the number of qualified people have also aggrandized. Now the companies are also having a wider choice to select the best candidates. But to the amazement of the industry the qualified people are not really equipped with the required skills. The gap between the skills required and possessed is very wide. It is not only the case the case of underdeveloped countries but for all the countries. In developed countries like US the following figure gives a glimpse of the status. 


\section{The skills gap is widening}

\section{Over the next decade nearly $31 / 2$ million manufacturing jobs will likely be needed and

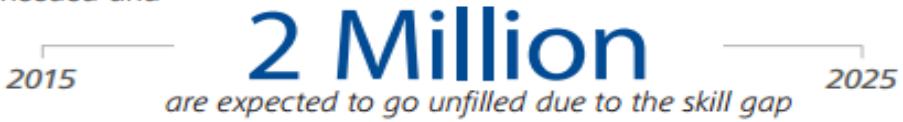

\section{The implications are significant \\ Every job in manufacturing creates another 2.5 new jobs in local goods and services.

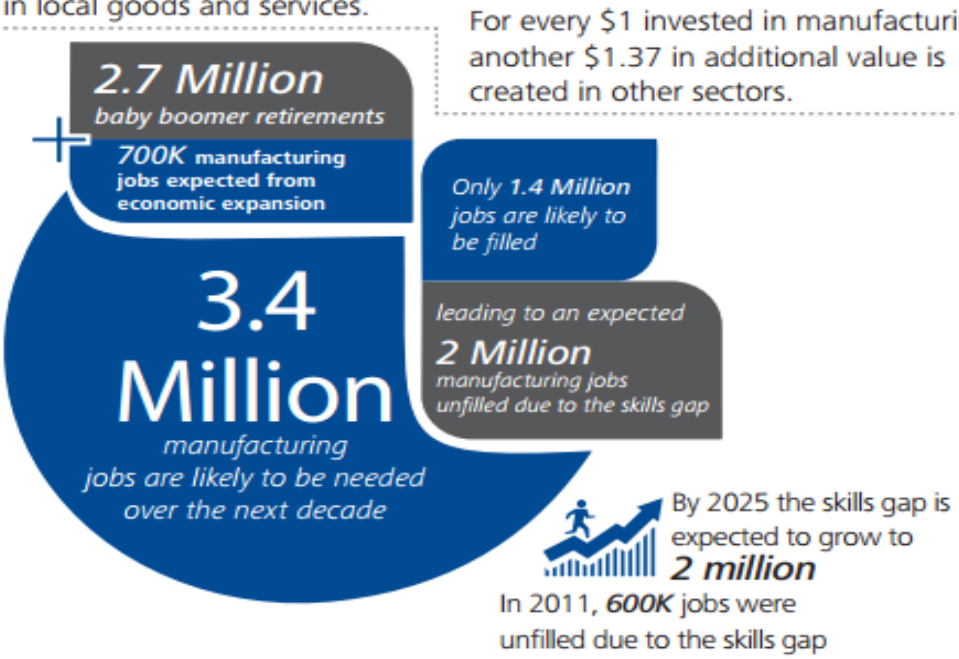

Source: Deloitte analysis based on data from U.S. Bureau of Labor Statisticse V and Gallup Sarvey:o PC set

In emerging countries like India is also not an exception for this skill gap.
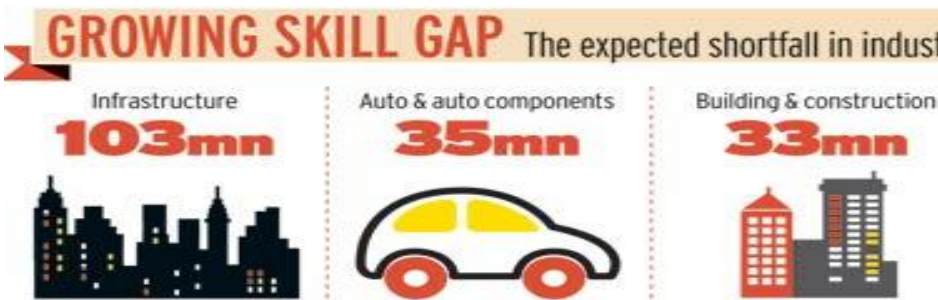

\section{2}
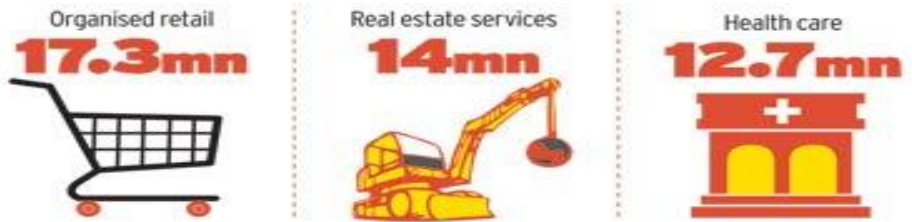
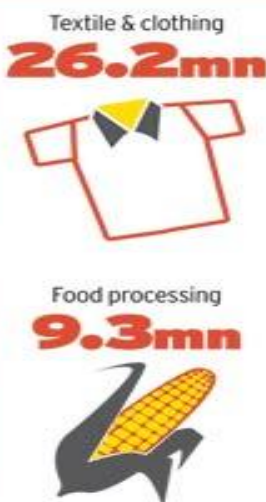

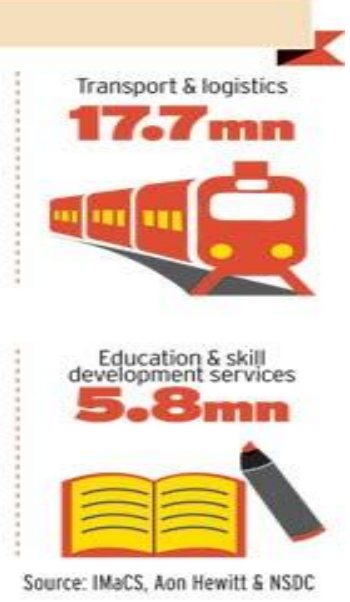

This is an alarming issue and need to be resolved as soon as possible.

India with over 1.3 billion population is in growth era now. It is emerging as the strong economy in Asia and will be World no. 1 very soon. It is with an initiative to rebuild, reinvent and reenergize. With a population of 1.3 billion, and with 0.8 billion in the young age, youthful India is surely expected to establish a brand in the world. But for that, there is a lot that is to be done and many challenges that are to be tackled. In this era of knowledge based economy, skilled and employment ready manpower is utmost important. Jobs and Skills have received the much needed focus and have taken the center stage. 


\section{THE REASONS FOR THE SKILL GAP IN INDIA:}

1. Industry: Industry is transforming a lot and increasing in quadrafold which is becoming difficult for the institutes to be on par with industry needs. The economy now is in the hands of tertiary sector and most importantly the software industry. The service sector needs only skilled labor and this is the need of the hour. The biggest challenge is that these skills are continuously upgraded to the next level. Thus even when institute is offering a course by the time they come out of the institute they are becoming outdated courses. Thus the fast pace is the problem from industry due to which the industry is also no providing much scope for practical training to the students in the form of internships.

2. Institutions: The number of institutions is increasing and competition is increasing which is creating a business environment for colleges. They are supposed to come with innovative strategies to attract students. Thus sometimes they are missing the real essence of teaching a student. Most of the institutes are trying to maintain many facilities to the students and encouraging the faculty but that is utilized by not more than $10 \%$ of students and faculty.

3. University: The University is coming with many innovative subjects but the curriculum is not supportive to teach all the concepts to the students. The curriculum is filled with theoretical approach rather than practical. The students are confined to classroom teaching in many of the institutes. The evaluation mode should also be modified.

4. Faculty: Every student is going to learn most of the things from their faculty or through the guidelines provided by the faculty. Thus a faculty is the role model for every student. The faculty should be a continuous learner in the sense that they should be a permanent student. The role of a faculty is not of giving lectures only but should be in a position to equip the students to face the real world. Thus a faculty should be skilled not only in technical skills but also in interpersonal, leadership, and emotional skills. They should be updating themselves with continuous research activities. But in the present days faculty is mere a job rather than a role. In the increasing competitive world with low pay when compared to industry standards, with low interest students and low encouraging environment they are losing their focus and delivering normal lectures to the students.

5. Students: The students on one hand are so innovative and on other hand are completely missing their focus. They are good at few things but ignoring the basic concepts without which they cannot continue their learning. A student is giving priority only marks which he can score by reading at the time of exams but ignoring the importance of practicing the concepts.

6. Corruption: Vyapam scam is the best example of corruption in our country. Not only in Madhya Pradesh but in many states the certificates are being sold and also government jobs. This is creating an environment where the students are trying ways to get marks and certificates rather than procure skills. Even many institutes are getting permissions without the basic facilities in the institute by the way of corruption.

7. Changing values and ethics: In the initial days the education was filled with values and ethics. But in the present days even though the values are there in education they are kept aside. The basic difference between the right and wrong is changed. The moral values are eroding from the minds of the people. A form of selfishness is occupying the minds of the people and the moral responsibility of questioning the wrong things is disappeared completely. Everybody are feeling that why should I ask.

8. Rural areas: The rural areas are filled with educational institutions but the abilities of the students are influenced by the culture of the areas and if they feel uncomfortable in learning they are just going back to do work in their villages. With the support of government and banking sector most of the students are coming and joining in the institutes but with a confidence that they can go back to their village and do any work to earn their livelihood. Thus the need for procuring skills and honing them is out of question for them. 


\section{REMEDIAL MEASURES TO REDUCE THE SKILL GAP}

The remedy for reducing the skill gap in India is to give utmost priority to Industry Institute Interaction. There should be regular interactions between the industry personnel and academicians. They should together forecast the needs of the industry and train the students in those areas. The institutes should also come out of regular and traditional courses but should be updated to provide the new courses. This is possible if the University is ready to provide that type of curriculum. Thus there should be a proper relation between the industry and university in framing the syllabus, mode of evaluation and increasing role of research activities. The curriculum should be in such a manner that it should provide scope for more training and research. Every institute should force its Industry Institute Interaction Cell to function vigorously. This will help in identifying the needs of the industry regularly and develop facilities to equip the students. Even when a company is coming for campus placements the III Cell should first concentrate the skills that are required and guide the training and placement departments towards achieving the jobs for students. This will transform the way of teaching by the faculty and the results will be in quantitative and qualitative measures. When the cell is active the students need not search for the ways of getting certificates in illegal manner or get fake certificates. When the educational institutions equip the students suitable to the industry needs, they can also develop them as the best citizens to our country filled with greatest cultural values in the world that is Indian cultural values and ethics. Thus the vision 2020 of transforming India into skilled nation can be taken up as a mission and accomplish it.

\section{OTHER MEASURES}

- Educate the students with research oriented activities.

- Faculty must upgrade their skills continuously.

- Universities must be dynamic in designing the curriculum with contemporary concepts.

- The institutions should provide all the facilities that are required to enrich the students to their maximum potential.

\section{Conclusion:}

India, a great nation with huge population and natural resources, but filled with great values and traditions is going to become the super power in the near future with the support of the young generation. Population, once limitation of India has become the greatest asset in developing our country. Now this asset, the population should become capital of India on which we can invest our future India.

\section{References:}

- https://wheebox.com/logo/ISR-2016-small.pdf

- http://www.cii.in 